\title{
Detection of Phytoplasma by Polymerase Chain Reaction of Insect Feeding Medium and Its Use in Determining Vectoring Ability
}

\author{
E. Tanne, E. Boudon-Padieu, D. Clair, M. Davidovich, S. Melamed, and Meir Klein
}

First, fourth, and sixth authors: Agricultural Research Organization, The Volcani Center, Bet Dagan 50250, Israel; second and third authors: BBCE-IPM Equipe Phytoplasmas, INRA, Dijon, France; and fifth author: The Hebrew University, Faculty of Agricultural, Food, and Environmental Sciences, Rehovot 76100, Israel.

Accepted for publication 12 April 2001.

\section{ABSTRACT}

Tanne, E., Boudon-Padieu, E., Clair, D., Davidovich, M., Melamed, S., and Klein, M. 2001. Detection of phytoplasma by polymerase chain reaction of insect feeding medium and its use in determining vectoring ability. Phytopathology 91:741-746.

A polymerase chain reaction (PCR)-based method was developed for the detection of phytoplasma in insect feeding medium (sucrose). A correlation was established between the transmissibility of Flavescence dorée phytoplasma in the experimental leafhopper vector Euscelidius variegatus and its detection by PCR in the insect feeding medium. However, phytoplasma were detected in the insects' bodies 3 weeks before they began to transmit. Hence, PCR assays of the sucrose medium reflected phytoplasma vectoring ability probably by detecting it in the insect saliva, whereas detection of phytoplasma in the insect's body did not identify it as a vector. The assay was applied to two field-collected leafhoppers suspected of being phytoplasma vectors in Israel (Orosius albicinctus and Anaceratagallia laevis). The presence of phytoplasma in the body of specimens of the latter species was assayed by PCR in 1999. Phytoplasmas were detected in insects' bodies throughout the year, with no specific seasonal pattern. In the saliva, however, no phytoplasma could be detected in the autumn. This seasonal pattern supported the validity of the feeding-medium tests and their correlation to the insect's ability to transmit phytoplasma. Transmission assays indicated, to our knowledge for the first time, that $O$. albicinctus and A. laevis are vectors of phytoplasma in Israel. A simple PCR-based assay is thus provided, circumventing the need for tedious biological assays and enabling epidemiological studies of phytoplasma transmissibility on a large scale.

Additional keyword: yellows diseases.
Phytoplasmas are known causal agents of hundreds of diseases of various plants (36). They are transmitted via propagation material (in the case of vegetatively propagated plants) and by specific phloem-feeding Euhemiptera (Cicadellidae and Fulgoromorpha) and Psyllidae. Leafhopper and planthopper species are the primary phytoplasma and spiroplasma vectors $(4,8,20,21,34,36,45)$, but psyllids have been reported as vectors of the European diseases of fruit trees $(2,6,16,38)$.

In the last decade, yellows diseases have been spreading throughout Israel, severely damaging various crops. Phytoplasmas belonging to different groups, such as aster yellows (AY), stolbur (STOL), and western X (WX, a Canadian X-similar type), have all been associated with yellows symptoms. They cause great economic losses in grapevine and carrots $(13,17,39,47)$. Whereas AY and STOL are ubiquitous $(21,33,44,45)$, the host range of WX-group phytoplasma is considered more restricted. Phytoplasmas of the WX group, first described in Prunus spp. (24), have been detected in grapevines in New York, Virginia, and Israel (13, 41,47).

The spread and progress of plant diseases are influenced by inoculum density and by the activity of vectors. Information is thus needed on potential vectors and inoculum sources to predict the risk of new infections (in one or multiple crops), to monitor disease progress, and to develop control methods.

Some phytoplasmas, such as AY, are transmitted by a number of leafhopper species. Furthermore, a single type of phytoplasma, American aster yellows, is transmitted by the leafhopper Macro-

Corresponding author: E. Tanne; E-mail address: tanne@agri.huji.ac.il

Publication no. P-2001-0531-01R

(C) 2001 The American Phytopathological Society stelles facifrons Stal, to more than 200 plant species belonging to different botanical families (36). In other cases, the phytoplasmavector relationship is more specific, in that only one insect species is able to transmit one phytoplasma type (37). Flavescence dorée (FD) phytoplasma in grapevines is specifically transmitted in nature by Scaphoideus titanus $(4,7,40,43)$, which feeds only on grapevine. In addition, only Neolaiturus fenestratus H.S., has been reported to transmit phytoplasma in Israel (42).

The incidence of phytoplasmas and spiroplasmas in phloemfeeding insects can be determined by bioassay, e.g., by feeding insects on experimental hosts $(4,6,16,21,22,32,34,35,40,42,43,45)$, or by applying direct methods to detect phytoplasmas in insects. Serological methods such as enzyme-linked immunosorbent assay (ELISA), immunosorbent electron microscopy, or immunolocalization in the microscope have been applied since the 1980s $(3,4$, 9-11,21,24,27-29,40) to detect phytoplasmas or spiroplasmas in insects. More recently, molecular tools, such as nucleic acid hybridization $(12,25)$ or polymerase chain reaction (PCR), sometimes followed by restriction fragment length polymorphism analysis, have been developed for detection in plants and have been applied to the identification of potential phytoplasma vector species $(22$, $33,34,45,50)$. However, phytoplasma transmission by insect vectors is an active process with several key events. After feeding acquisition, multiplication and movement of the phytoplasma in the gut and haemocell, the penetration of phytoplasma into the salivary glands is a prerequisite to transmission $(4,19,20,23,27$, $29,37,49)$. Hence, the detection of phytoplasma in insects with one of the previously mentioned methods is a step toward the identification of a vector but is not evidence of its vectoring ability. Many phloem-feeding insects are capable of acquiring phytoplasmas and spiroplasmas from plants but are not capable of transmitting them $(1,5,15,48)$. Biological transmission assays are, 
therefore, the only way to ascertain phytoplasma transmissibility. However, they are tedious and require large quantities of phytoplasma-free insects and phytoplasma-susceptible plants on which the insects can feed and survive $(9,22,33,45)$. Therefore, they are not practical for large-scale epidemiological studies.

This paper presents an alternative to biological transmission assays, which can be used on a large scale to determine insect inoculativity. It consists of PCR detection of phytoplasmas in insect feeding medium (probably in the saliva) and is used as a tool to identify potential vectors of some of the yellows diseases in Israel. Parameters related to the transmission of phytoplasma by Euscelidius variegatus were previously established $(4,9,27)$. The feeding medium-detection assay was tested for correlation with the ability of this insect to transmit FD under controlled conditions. Initial transmission studies were carried out with several inoculative insects, proving their ability to transmit phytoplasma.

\section{MATERIALS AND METHODS}

Insect samples. The following is a description of the insects tested in Israel: Orosius albicinctus Matsumura was collected with a portable suction device several times over the summer and autumn of 1999. Insects were collected from Tribulus terrestris (Zygophyllaceae), various Brassica spp., and Amaranthus spp. (Chenopodiaceae). Anaceratagallia laevis (=Agallia laevis Rib [30]) was abundant on Gazania nivea, parsley, and many weeds in Golan Heights, Israel, from April to December. E. variegatus was laboratory-reared.
DNA isolation. DNA was extracted from plant tissue according to Daire et al. (14) and from insects according to Maixner et al. (33). Leaf tissue was ground in extraction buffer (100 mM Tris$\mathrm{HCl}$ at $\mathrm{pH} 8.0,3 \%$ cetyltrimethylammonium bromide (CTAB), $1.4 \mathrm{M} \mathrm{NaCl}, 20 \mathrm{mM}$ EDTA, and $0.2 \%$ 2-mercaptoethanol) at a ratio of 1:5 (wt/vol, tissue/buffer). DNA from insects was similarly extracted, but the buffer contained $2 \%$ CTAB. The slurry was incubated for $20 \mathrm{~min}$ at $60^{\circ} \mathrm{C}$ and centrifuged for $10 \mathrm{~min}$ at $3,000 \times \mathrm{g}$. The supernatant was collected and extracted with an equal volume of chloroform/isoamyl alcohol (24:1, vol/vol), followed by centrifugation and precipitation with 1 volume of isopropanol. Following 30-min incubation at $-20^{\circ} \mathrm{C}$, the DNA was pelleted at $12,000 \times g$ for $30 \mathrm{~min}$. The pellet was washed twice with $70 \%$ ethanol and resuspended in $50 \mu \mathrm{l}$ of $10 \mathrm{mM}$ Tris and $1 \mathrm{mM}$ EDTA at $\mathrm{pH} 8.0$ (TE). DNA was extracted from the sucrose-TE medium following insect feeding according to Zhang et al. (51). The sucrose solution was centrifuged at $12,000 \times g$ for $15 \mathrm{~min}$. $\mathrm{NaOH}$ $(0.5 \mathrm{~N} ; 10 \mu \mathrm{l})$ was added to the pellet, followed by $20 \mu \mathrm{l}$ of $1 \mathrm{M}$ Tris- $\mathrm{HCl}$ buffer, $\mathrm{pH} 8.0$, containing $1 \%$ sodium dodecyl sulfate, and $20 \mathrm{mM}$ EDTA. The mixture was incubated at $65^{\circ} \mathrm{C}$ for $15 \mathrm{~min}$, precipitated with 2 volumes of ethanol, and kept at $-20^{\circ} \mathrm{C}$ for at least $30 \mathrm{~min}$. DNA was precipitated by centrifugation at $12,000 \times g$ for $20 \mathrm{~min}$ and resuspended in 30 to $40 \mu \mathrm{l}$ of TE.

PCR. Screening for phytoplasmas in insect bodies and saliva was done by PCR with primers R16F2/R2 (26) or the primer-pair P1 (18) and P7 (46), followed by a nested PCR with primer-pair rU3/fU5 (31), resulting in an 860-bp product. Most of the phytoplasma detected in field-collected insects belonged to the AY
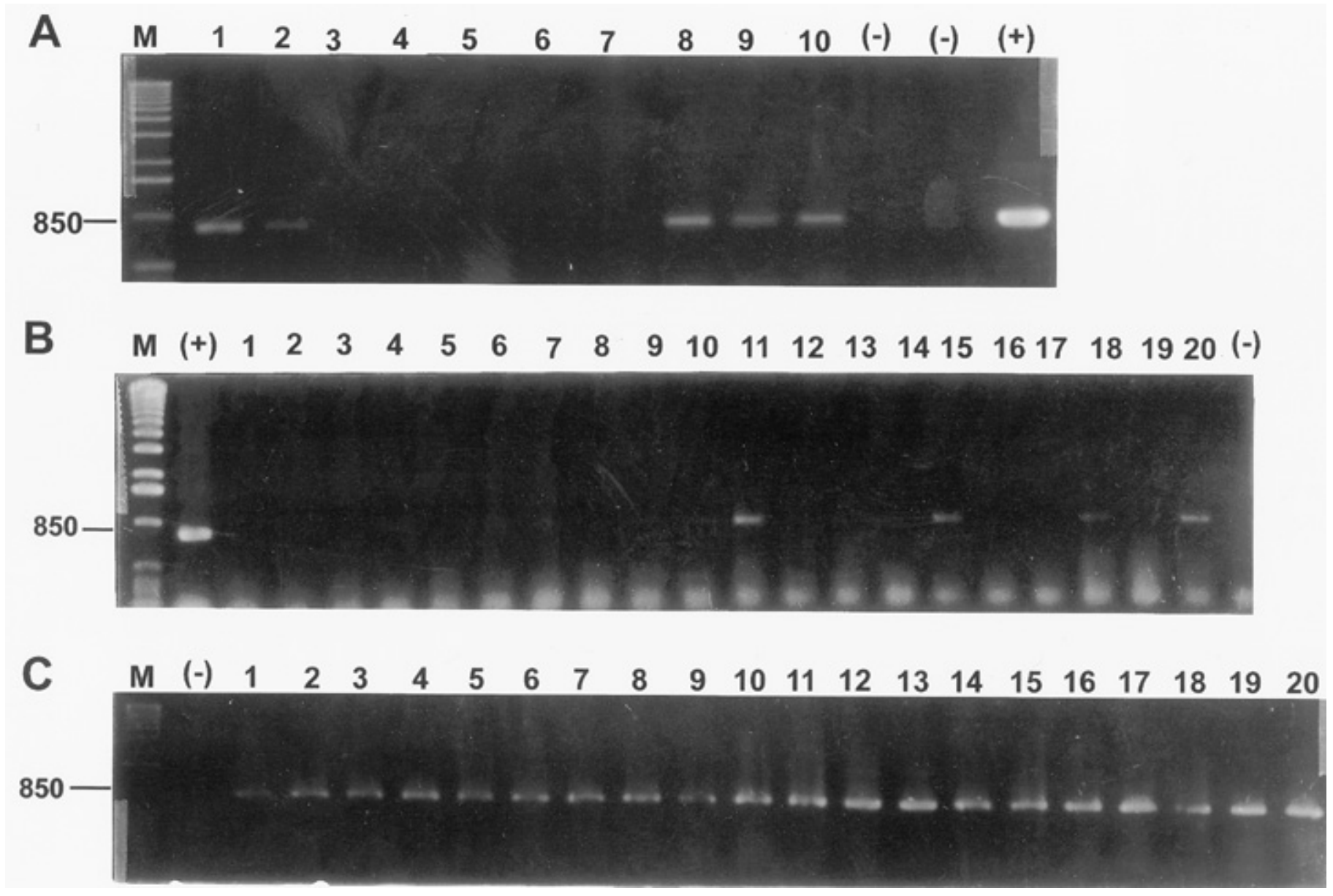

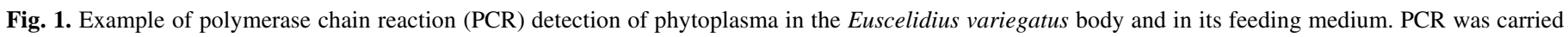

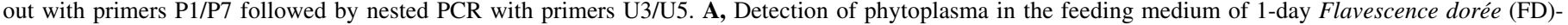

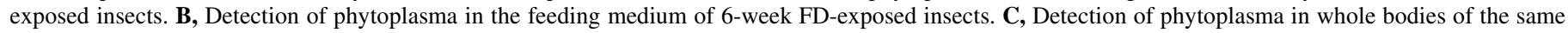

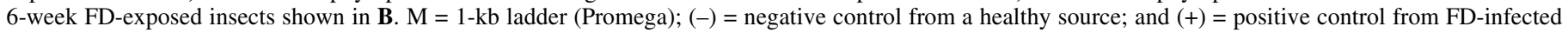
sample. Numbers represent individual insects (not necessarily the same insects presented in Table 1). 
group. Therefore, to increase sensitivity, screening was performed with primer-pair R16F2/R2 followed by a nested AY-specific PCR with primer pair R16(I)F1/R1 (26), giving rise to a product of approximately $1,100 \mathrm{bp}$. PCR products were analyzed by electrophoresis on a $1.2 \%$ agarose gel followed by staining with ethidium bromide and visualization of DNA bands with a UV transilluminator. Reference AY-type phytoplasmas (provided by R. E. Davis, Beltsville, MD) were maintained in periwinkle (Catharanthus roseus (L.) G. Don) and the DNAs extracted from them served as positive controls.

Inoculativity assays. A method reported by Zhang et al. (51) was adapted. White Eppendorf tubes $(1.5 \mathrm{ml})$ were used as insect chambers. The white tube caps were removed and replaced with yellow ones. The cylindrical cups in the yellow caps were filled with $200 \mu \mathrm{l}$ of $5 \%$ sucrose in TE and sealed with Parafilm. White microcentrifuge tubes were capped with the yellow caps carrying the sucrose-TE feeding medium in their sachets. The bottom ends of the microcentrifuge tubes were cut, an individual insect was placed in each, and the cut-end was sealed with cotton wool. Each tube, containing an individual leafhopper, was kept at 23 to $25^{\circ} \mathrm{C}$ for 48 to $72 \mathrm{~h}$ in a horizontal position with the cap facing a light source to attract the insects to the feeding medium. DNA was individually extracted from each feeding medium ration and analyzed by PCR for the presence of phytoplasma. Dead insects that had not survived the long period of artificial feeding were collected as well. Subsamples of the surviving insects were placed on test plants for transmission assays and PCR-tested for phytoplasma.

Procedure for correlating the inoculativity assays with the phytoplasma life cycle within the vector. E. variegatus leafhoppers were reared as healthy colonies in a controlled environment

TABLE 1. Polymerase chain reaction (PCR) detection of phytoplasma in Tris-EDTA (TE)-sucrose feeding medium and in whole bodies of individual Euscelidius variegatus leafhoppers during phytoplasma acquisition, latency, and the inoculative state ${ }^{a}$

\begin{tabular}{lccc}
\hline $\begin{array}{l}\text { Days after } \\
\text { acquisition }\end{array}$ & $\begin{array}{c}\text { PCR of TE- } \\
\text { sucrose }^{\mathrm{b}}\end{array}$ & $\begin{array}{c}\text { PCR of whole } \\
\text { insect }^{\mathrm{b}}\end{array}$ & $\begin{array}{c}\text { Transmission to } \\
\text { broad bean }^{\mathrm{c}}\end{array}$ \\
\hline 1 day & $5 / 10$ & $10 / 10$ & $\mathrm{NT}$ \\
4 days & $2 / 20$ & $11 / 20$ & $\mathrm{NT}$ \\
7 days & $0 / 20$ & $3 / 4$ & $0 / 5$ \\
14 days & $0 / 20$ & $16 / 16$ & $0 / 7$ \\
21 days & $1 / 20$ & $18 / 18$ & $3 / 14$ \\
28 days* & $3 / 20$ & $19 / 19$ & $1 / 3$ \\
35 days* & $9 / 20$ & $14 / 14$ & $3 / 5$ \\
42 days & $6 / 20$ & $18 / 18$ & $5 / 17$ \\
49 days & $13 / 20$ & $16 / 17$ & $7 / 13$ \\
56 days & $5 / 20$ & $\mathrm{NT}$ & $\mathrm{NT}$ \\
\hline
\end{tabular}

a NT, not tested. * Indicates low survival on TE-sucrose.

b Positive/total tested.

c Symptomatic plants/total number of plants inoculated with feeding insects.

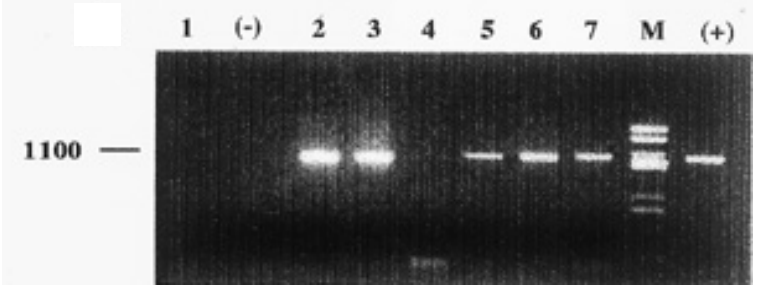

Fig. 2. Example of polymerase chain reaction (PCR) detection of phytoplasma in the bodies of field-collected Orosius albicinctus. PCR was carried out with universal primers R16F2/R2 followed by nested PCR with aster yellows-specific primers. $\mathrm{M}=$ size markers: pBR322 cleaved with Alw44I and $M v a \mathrm{I}$ (MBI Fermentas); $(-)=$ negative control; and $(+)=$ positive control. Numbers represent individual insects (not necessarily corresponding to the insects presented in Table 2). (photoperiod $16 / 8 \mathrm{~h}, 22^{\circ} \mathrm{C}, 80 \%$ humidity) (8). Leafhoppers in each colony were hatched simultaneously and were assumed to be of the same age. To obtain a $100 \%$ infected colony, young leafhoppers from a healthy colony were fed on FD-infected broad bean (Vicia faba), allowing a 14-day acquisition period, and transferred to healthy corn plants (Zea mays) that were immune to FD phytoplasma (8). According to previous data, a latent period of 3 to 5 weeks from the beginning of acquisition is required until phytoplasmas enter the salivary glands and the insect becomes infective $(4,27,29)$.

Once or twice weekly, starting from the first day of acquisition, a batch of 20 insects was taken from an infected colony and individually fed on sucrose for 3 days as described previously. Surviving leafhoppers were transferred, one insect per plant, to healthy broad bean seedlings for a transmission period of 1 week. Dead insects were also collected. PCR assays were carried out with DNA from individual whole insect bodies (including dead insects), as well as from individual rations of the sucrose feeding medium. Actual transmission was followed up by symptom appearance on broad beans.

Transmission experiments with field-collected insects. Fieldcollected insects of phytoplasma-carrying species (as previously determined by PCR) were individually caged on periwinkle, potato, and cotton seedlings for an inoculation access period of 3 days. The seedlings were sprayed with insecticides and kept in a greenhouse for symptom observation and PCR analysis.

TABLE 2. Polymerase chain reaction (PCR) detection of phytoplasma in feeding sucrose solutions and insect bodies of field-collected insects in 1999

\begin{tabular}{llcc}
\hline $\begin{array}{l}\text { Leafhopper } \\
\text { collection date }\end{array}$ & Leafhopper & $\begin{array}{c}\text { Feeding } \\
\text { medium }^{\mathrm{a}}\end{array}$ & $\begin{array}{c}\text { Insect } \\
\text { bodies }^{\mathrm{a}}\end{array}$ \\
\hline 1 June & Orosius albicinctus & $23 / 33$ & $3 / 5$ \\
11 June & Orosius albicinctus & $18 / 40$ & $7 / 8$ \\
2 July & Orosius albicinctus & $8 / 14$ & $14 / 15$ \\
6 August & Orosius albicinctus & $22 / 24$ & $9 / 9$ \\
11 August & Orosius albicinctus & $20 / 46$ & $17 / 22$ \\
21 September & Orosius albicinctus & $0 / 47$ & $14 / 20$ \\
6 October & Orosius albicinctus & $0 / 40$ & $16 / 21$ \\
7 November & Orosius albicinctus & $0 / 3$ & $11 / 24$ \\
10 June & Anaceratagallia laevis & $12 / 13$ & $7 / 7$ \\
13 July & Anaceratagallia laevis & $18 / 46$ & $18 / 40$ \\
11 August & Anaceratagallia laevis & $14 / 45$ & $22 / 26$ \\
6 October & Anaceratagallia laevis & $0 / 46$ & $11 / 11$ \\
7 November & Anaceratagallia laevis & $0 / 7$ & $4 / 4$ \\
\hline
\end{tabular}

a Ratio of PCR positives to total number of assayed insects.

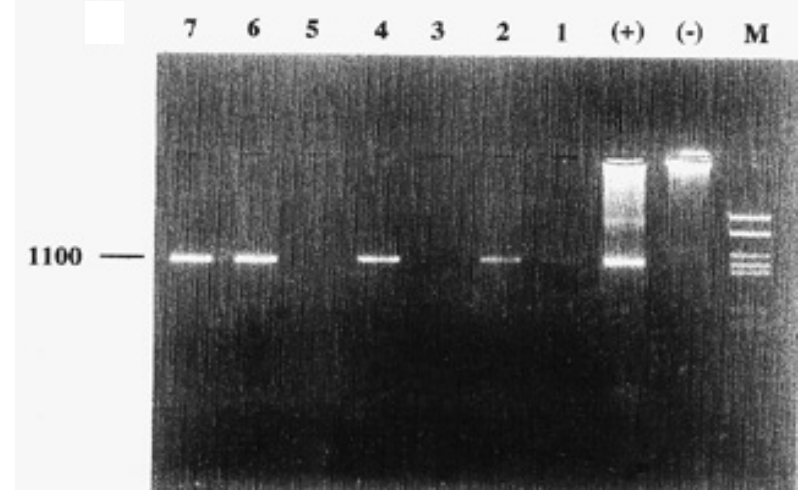

Fig. 3. Example of polymerase chain reaction (PCR) detection of phytoplasma in the sucrose feeding medium of field-collected Orosius ablicinctus. PCR was carried out with universal primers R16F2/R2 followed by nested PCR with aster yellows-specific primers. $M=$ size markers: pBR322 cleaved with Alw44I and MvaI (MBI Fermentas); $(-)=$ negative control; and $(+)=$ positive control. Numbers represent individual insects (not necessarily corresponding to the insects presented in Table 2). 


\section{RESULTS}

Detection of phytoplasma in sucrose following artificial feeding correlated with the inoculative state of $\boldsymbol{E}$. variegatus. Survival of E. variegatus leafhoppers on the sucrose-TE diet was more than $50 \%$ after 3 days, except for leafhoppers in the fourth and fifth week after the beginning of acquisition for which survival was lower. This is the critical time of phytoplasma penetration into the salivary glands, rendering the insects infectious $(4,27)$.

Representative PCR results obtained from sucrose and insect samples are shown in Figure 1. When FD-infected leafhoppers were assayed for the presence of phytoplasma in their bodies, nearly all leafhoppers in each batch, regardless of being inoculative or not, carried phytoplasma (Table 1). Phytoplasma DNA was detected in the feeding medium 1 and 4 days after acquisition but not during the latent period. It also was present from the third week on, despite the poor survival of leafhoppers. During this same period, the surviving insects could transmit to broad beans.

Field tests: PCR detection of phytoplasma in leafhopper bodies and feeding medium. PCR assays with primers R16F2/R2, followed by nested PCR with AY-specific primers R(I)F1/R1, were performed with DNA from leafhoppers collected during the spring, summer, and autumn in Golan Heights. An example of the PCR tests identifying phytoplasma-carrying insects is given in Figure 2. Table 2 summarizes the results of all PCR assays of the insect bodies. Phytoplasma-carrying $O$. albicinctus and $A$. laevis were detected throughout this period.

Leafhoppers, collected in and around vineyards in Golan Heights, were fed on sucrose solution. DNA was extracted from these solutions and analyzed by PCR. Phytoplasma detected in the sucrose solution probably indicated the presence of the pathogen in the insect's saliva (Fig. 3). Phytoplasmas were detected in sucrose solutions following feeding of leafhoppers trapped from June through August. Phytoplasma could not, however, be detected in the feeding medium of insects collected in September, October, or November (Table 2). A seasonal pattern was thus observed, probably reflecting environmental influence on the ability of the insects to transmit. The sucrose assay, therefore, reflected a biological state, and (as with the association found in E. variegatus) a pattern was exhibited again.

Transmission assays with field-collected insects. The results of the transmission assays with insects collected from the field and allowed to feed on test plants are summarized in Table 3. Based on symptom appearance and PCR assays of the test plants, field-collected $O$. albicinctus and $A$. laevis were able to transmit phytoplasma to periwinkle and potato plants. In addition, $O$. albicinctus transmitted phytoplasma to cotton.

\section{DISCUSSION}

Previous reports established the cycle parameters of FD transmission by $E$. variegatus $(4,27,29)$. In experiments with laboratory-reared $E$. variegatus, the detection of phytoplasma in sucrose solutions following insect feeding correlated with the cycle of FD transmission by this insect. However, on the first and fourth day from the beginning of acquisition, phytoplasmas were found in the feeding medium but later disappeared. These phytoplasmas proba-

TABLE 3. Transmission of phytoplasma from leafhoppers to plants

\begin{tabular}{lcc}
\hline Insect & Recipient plant & Relative infection $^{\mathrm{a}}$ \\
\hline Anaceratagallia laevis & Periwinkle & $1 / 1$ \\
Anaceratagallia laevis & Potato & $1 / 1$ \\
Orosius albicinctus & Periwinkle & $2 / 4$ \\
Orosius albicinctus & Potato & $3 / 3$ \\
Orosius albicinctus & Cotton & $1 / 1$ \\
\hline
\end{tabular}

a Number of infected plants/number of plants tested. bly were residual ones that had adhered to the stylet tissues upon feeding. Similar observations have been previously reported, in which FD could be detected by ELISA in individual alimentary tracts during the first week after acquisition (27), and again, only when the insect was inoculative. Hence, the detection of phytoplasma in the sucrose medium is presumably due to the presence of the pathogen in the insect saliva, secreted into the solution upon feeding. We detected phytoplasma in the insect bodies 3 weeks before the insects transmitted it; therefore, detection of phytoplasma in insects does not indicate that the insect is inoculative. Indeed, it has been reported that nonvector insects can acquire phytoplasma without being able to transmit the pathogen $(1,15$, 48). Thus, the experiments with the laboratory-reared leafhoppers provided evidence of the validity of the feeding-medium tests.

Experiments with field-collected insects corroborated the correlation between the detection of phytoplasma in the feeding medium and transmission. Two suspected phytoplasma vectors, $O$. albicinctus and A. laevis, were collected throughout an entire season in and around phytoplasma-infested vineyards in Golan Heights. The detection of phytoplasma in the feeding medium showed a seasonal pattern; phytoplasma could not be detected in the autumn (Table 3). In contrast, no time-related pattern was indicated for phytoplasma detection in the insects' bodies (Table 2).

Control measures for vector-transmitted diseases are greatly facilitated when vectors have been identified and their transmission parameters determined. However, large-scale biological assays for the identification of vectors are impractical. Transmission assays may also fail due to use of unsuitable host plants, because host-specific transmission has been recorded $(40,43)$. Detection of phytoplasma in insect bodies is not a reliable predictor of their ability to transmit. The PCR test of artificial diets provides an easy and reliable way to determine insect inoculativity and bypasses possible hindrances engendered by species specificity. It also enables large-scale testing.

Although phytoplasma occurrences in Israel have been reported in the past (42), they did not constitute an agronomic problem until a decade ago. The sudden emergence of phytoplasma-related diseases and their rapid spread is cause for concern, especially because they have reached epidemic levels in certain grapevine varieties and in carrot $(13,17,39,47)$. The study of epidemiological factors, especially the ability of phytoplasma to be vectored, is a prerequisite for understanding emergence and spread of these diseases, as well as for devising control measures.

This paper describes the adaptation and development of tools enabling a large-scale study of phytoplasma transmission in the perplexing field of phytoplasma epidemiology in Israel. To our knowledge, this is the first report to demonstrate the presence of phytoplasma in insects in Israel and suggests the circulative nature of the insect-pathogen interaction. It also confirms previous reports on the occurrence of phytoplasma in plants in Israel (13, $17,39,42,47)$. To our knowledge, this is the first report of $O$. albicinctus and A. laevis as vectors of phytoplasma in Israel.

\section{ACKNOWLEDGMENTS}

This research was funded, in part, by the Chief Scientist of the Ministry of Agriculture and the Israeli Vegetable Board. This paper is a contribution from the Agricultural Research Organization, Institute of Plant Protection, Bet Dagan, Israel 512/01.

\section{LITERATURE CITED}

1. Albanese, G. D., Urso, V., Granata, G., and Colladoro, S. 1997. Individuazione di un fitoplasma in esemplari di Psamotettix striatus catturati in vigneti. Inform. Fitopathol. 7/8:57-60.

2. Alma, A., Navone, P., Visentin, C., Arzone, A., and Bosco, D. 2000. Rilevamento di fitoplasmi di Apple proliferation in Cacopsylla melanoneura (Förster) (Homoptera Psyllidae). Petria 10:141-142.

3. Archer, D. B., Townsend, R., and Markham, P. G. 1982. Detection of 
Spiroplasma citri in plants and insect hosts by ELISA. Plant Pathol. 31:299-306.

4. Boudon-Padieu, E., Larrue, J., and Caudwell, A. 1989. ELISA and dotblot detection of Flavescence dorée-MLO in individual leafhopper vectors during latency and inoculative state. Curr. Microbiol. 19:357-364.

5. Bové, J.-M., Moutous, G., Saillard, C., Fos, A., Bonfils, J., Vignault, J.-C., Nhami, A., Abassi, M., Kabbage, K., Hafidi, B., Mouches, C., and Viennot-Bourgin, G. 1979. Mise en évidence de Spiroplasma citri, l'agent causal de la maladie du "stubborn" des agrumes, dans 7 cicadelles du Maroc. C. R. Acad. Agric. Fr. 288:335-338.

6. Carraro, L., Osler, R., Loi, N., Ermacora, P., and Refati, E. 1998. Transmission of European stone fruit yellows phytoplasma by Cacopsylla pruni. J. Plant Pathol. 80:233-239.

7. Caudwell, A., Gianotti, J., Kuszala, C., and Larrue, J. 1971. Etude du rôle de particules de type "Mycoplasme" dans l'étiologie de la Flavescence dorée de la Vigne. Examen cytologique des plantes malades et des cicadelles infectieuses. Ann. Phytopathol. 3:107-123.

8. Caudwell, A., and Larrue, J. 1977. La production de cicadelles saines et infectieuses pour les épreuves d'infectivité chez les jaunisses à Mollicutes des végétaux. Ann. Zool. Ecol. Anim. 9:443-456.

9. Caudwell, A., Meignoz, R., Kuszala, C., Schneider, C., Larrue, J., Fleury, A., and Boudon-Padieu, E. 1982. Purification sérologique et visualisation au microscope électronique de l'agent pathogène (MLO) de la flavescence dorée de la vigne dans les extraits de vecteurs infectieux et dans les extraits de plantes malades. C. R. Seances Soc. Biol. 176:723-729.

10. Chen, K. H., Guo, J. R., Wu, X. Y., Loi, N., Carraro, L., Guo, Y. H., Chen, Y. D., Osler, R., Pearson, R., and Chen, T. A. 1993. Comparison of monoclonal antibodies, DNA probes, and PCR for detection of the grapevine yellows disease agent. Phytopathology 83:915-922.

11. Chen, T. A., Lei, J. D., and Lin, C. P. 1989. Detection and identification of plant and insect mollicutes. Pages 393-424 in: The Mycoplasmas. Vol. 5. Spiroplasmas, Acholeplasmas, and Mycoplasmas of Plants and Arthropods. R. F. Whitcomb and J. G. Tully, eds. Academic Press, San Diego.

12. Daire, X., Boudon-Padieu, E., Bervillé, A., A. 1992. Cloned DNA probes for detection of grapevine Flavescence doree mycoplasma-like organism (MLO). Ann. Appl. Biol. 121:95-103.

13. Daire, X., Clair, D., Larrue, J., Boudon-Padieu, E., Alma, A., Arzone, A., Carraro, L., Osler, R., Refatti, E., Granata, G., Credi, R., Tanne, E., Pearson, A., and Caudwell, A. 1993. Occurrence of diverse MLOs in tissues of grapevine affected by grapevine yellows in different countries. Vitis 32:247-248.

14. Daire, X., Clair, D., Reinert, W., and Boudon-Padieu, E. 1997. Detection and differentiation of grapevine yellows phytoplasmas belonging to the elm yellows group and to the stolbur subgroup by PCR amplification of non-ribosomal DNA. Eur. J. Plant Pathol. 103:507-514.

15. Danielli, A., Bertaccini, A., Vibio, M., Mori, N., Murari, E., Posenato, G., and Girolami, V. 1996. Detection and molecular characterization of phytoplasmas in the planthopper Metcalfa pruinosa (Say) (Homoptera: Flatidae). Phytopathol. Mediterr. 35:62-75.

16. Davies, D. L., Guise, C. M., Clark, M. F., and Adams, A. N. 1992. Parry's disease of pears is similar to pear decline and is associated with mycoplasma-like organisms transmitted by Cacopsylla pyricola. Plant Pathol. 41:195-203.

17. Davis, R. E., Tanne, E., and Rumbos, I. C. 1997. Phytoplasma associated with grapevine yellows in Israel and Greece belong to the stolbur phytoplasma subgroup 16SRXII-A. J. Plant Pathol. 79:181-187.

18. Deng, S., and Hiruki, C. 1991. Amplification of 16S rRNA genes from culturable and nonculturable mollicutes. J. Microbiol. Methods 14:53-61

19. Fletcher, J., Shaw, M. E., Baker, G. R., Dugan, K. J., Ye, F., Sha, Y., Zuck, P. D., and Myers, G. D. 1996. Molecular characterization of Spiroplasma citri BR3 lines that differ in transmissibility by the leafhopper Circulifer tenellus. Can. J. Microbiol. 42:124-131.

20. Fos, A., Bové, J. M., Lallemand, J., Saillard, C., Vignault, J. C., Ali, Y., Brun, P., and Vogel, R. 1986. La cicadelle Neoaliturus haematoceps (Mulasant \& Rey) est vecteur de Spiroplasma citri en Méditerranée. Ann. Inst. Pasteur/Microbiol. 137:97-107.

21. Fos, A., Danet, J. L., Zreik, L., Garnier, M., and Bove, J. M. 1992. Use of a monoclonal antibody to detect stolbur mycoplasmalike organism in plants and insects and to identify a vector in France. Plant Dis. 76:10921096.

22. Gatineau, F., Larrue, J., Clair, D., Lorton, F., Richard-Molard, M., and Boudon-Padieu, E. 2001. A new natural planthopper vector of stolbur phytoplasma in the genus Pentastiridius (Hemiptera: Cixiidae). Eur. J. Plant Pathol. 107:263-271.

23. Harris, K. F. 1980. Aphids, leafhoppers and planthoppers. Pages 1-13 in: Vectors of Plant Pathogens. K. F. Harris and K. Maramorosch, eds. Academic Press, New York.

24. Kirkpatrick, B. C., and Garrott, D. G. 1984. Detection of X-disease in plant hosts by enzyme-linked immunosorbent assay. (Abstr.) Phyto- pathology 74:S825.

25. Kirkpatrick, B. C., Stenger, D. C., Morris, T. J., and Purcell, A. H. 1987. Cloning and detection of DNA from a nonculturable plant pathogenic mycoplasma-like organism. Science 238:197-200.

26. Lee, I.-M., Gundersen, D. E., Hammond, R. W., and Davis, R. E. 1994. Use of mycoplasmalike organisms (MLO) group-specific oligonucleotide primers for nested-PCR assays to detect mixed-MLO infections in a single host plant. Phytopathology 84:559-566.

27. Lefol, C., Lherminier, J., Boudon-Padieu, E., Larrue, J., Louis, C., and Caudwell, A. 1994. Propagation of Flavescence dorée MLO (mycoplasma-like organism) in the leafhopper vector Euscelidius variegatus Kbm. J. Invert. Pathol. 63:285-293.

28. Lherminier, J., Prensier, G., Boudon-Padieu, E., and Caudwell, A. 1989. Immunolabelling of grapevine Flavescence dorée MLO in salivary glands of Euscelidius variegatus: A light and electron microscopy study. J. Histochem. Cytochem. 38:79-85.

29. Lherminier, J., Terwisscha van Scheltinga, T., Boudon-Padieu, E., and Caudwell, A. 1989. Rapid immuno-fluorescence detection of the grapevine Flavescence dorée in the salivary glands of the leafhopper Euscelidius variegatus Kbm. Phytopathol. Z. 125:353-360.

30. Linnavuori, R. 1962. Hemiptera of Israel III. Ann. Zool. Soc. "Vanamo" 24:1-108.

31. Lorenz, K.-H., Schneider, B., Ahrens, A., and Seemüller, E. 1995. Detection of the apple proliferation and pear decline phytoplasmas by PCR amplification of ribosomal and nonribosomal DNA. Phytopathology 85:771-776.

32. Maixner, M. 1994. Transmission of German grapevine yellows (Vergilbungskrankheit) by the planthopper Hyalethes obsoletus (Auchenorrhyncha: Cixiidae). Vitis 33:103-104.

33. Maixner, M., Ahrens, U., and Seemüller, E. 1995. Detection of German grapevine yellows (Vergilbungskrankheit) MLO in grapevine, alternative hosts and vector by a specific PCR procedure. Eur. J. Phytopathol. 101:241-250.

34. Maixner, M., and Reinert, W. 1999. Oncopsis alni (Schrank) Schneider, B., and Caudwell, (Auchenorrhyncha: Cicadellidae) as a vector of the alder yellows phytoplasma of Alnus glutinosa (L.) Gaertn. Eur. J. Plant Pathol. 105:87-94.

35. Maramorosch, K. 1953. Incubation period of aster yellows virus. Am. J. Bot. 40:797-809.

36. McCoy, R. E., Caudwell, A., Chang, C. J., Chen, T. A., Chiykowski, L. N., Cousin, M. T., Dale, J. L., de Leeuw, G. T. N., Golino, D. A., Hacket, K. J., Kirkpatrick, B. C., Marvitz, R., Petzold, H., Sinha, R. C., Sugiura, M., Whitcomb, R. F., Yang, I. L., Zhu, B. M., and Seemüller, E. 1989. Plant diseases associated with mycoplasma-like organisms. Pages 545640 in: The Mycoplasmas. Vol. 5. Spiroplasmas, Acholeplasmas, and Mycoplasmas of Plants and Arthropods. R. F. Whitcomb and J. C. Tully, eds. Academic Press, San Diego.

37. Nielson, M. E. 1968. The leafhopper vectors of phytopathogenic viruses (Homoptera: Cicadellidae). Taxonomy, biology and virus transmission. U.S. Dep. Agric. Tech. Bull. 1382.

38. Nyland, G., and Moller, W. J. 1973. Control of pear decline with tetracycline. Plant Dis. Rep. 57:634-637.

39. Orenstein, S., Frank, A., and Tanne, E. 1999. Association of a phytoplasma with a carrot disease in Israel. J. Plant Pathol. 81:193-199.

40. Osler, R., Boudon-Padieu, E., Carraro, L., Caudwell, A., and Refati, E. 1992. First results to the trials in progress to identify the agent of a grapevine yellows in Italy. Phytopathol. Mediterr. 31:175-181.

41. Prince, J. P., Davis, R. E., Wolf, T. K., Lee, I.-M., Mogen, B. D., Dally, E. L., Bertaccini, A., Credi, R., and Barba, M. 1993. Molecular detection of diverse mycoplasmalike organisms (MLOs) associated with grapevine yellows and their classification with aster yellows, X-disease, and elm yellows MLOs. Phytopathology 83:1130-1137.

42. Raccah, B., and Klein, M. 1982. Transmission of the safflower phyllody mollicute by Neolaiturus fenestratus. Phytopathology 72:230-232.

43. Schvester, D., Carle, P., and Mouttous, G. 1961. Sur la transmission de la Flavescence dorée des vignes par une cicadelle. C. R. Acad. Agric. 47:1021-1024.

44. Seemüller, E., Marcone, C., Lauer, U., Ragozzino, A., and Göschl, M. 1998. Current status of molecular classification of the phytoplasmas. J. Plant Pathol. 80:3-26.

45. Sforza, R., Clair, D., Daire, X., Larrue, J., and Boudon-Padieu, E. 1998. The role of Hyalesthes obsoletus (Hemiptera: Cixiidae) in the occurrence of bois noir of grapevine in France. J. Phytopathol. 146:549-556.

46. Smart, C. D., Schneider, B., Blomquist, C. L., Guerra, L. J., Harrison, N. A., Ahrens, U., Seemüller, E., and Kirkpatrick, B. C. 1996. Phytoplasmaspecific PCR primers based on sequences of the 16S-23S rRNA spacer region. Appl. Environ. Microbiol. 62:2988-2993.

47. Tanne, E., and Orenstein, S. 1997. Identification and typing of grapevine yellows phytoplasma amplified by graft transmission to periwinkle. Vitis 
36:35-38.

48. Vega, F. E., Davis, R. E., Barbosa, P., Dally, E. L., Purcell, A. H., and Lee, I.-M. 1993. Detection of a plant pathogen in a nonvector insect species by the polymerase chain reaction. Phytopathology 83:621-624.

49. Wayadande, A. C., and Fletcher, J. 1995. Transmission of Spiroplasma citri lines and their ability to cross gut and salivary gland barriers within the leafhopper vector Circulifer tenellus. Phytopathology 85: 1256-1259.
50. Weber, A., and Maixner, M. 1998. Survey of populations of the planthopper Hyalesthes obsoletus Sign. (Auchenorrhyncha: Cixiidae) for infection with the phytoplasma causing grapevine yellows in Germany. J. Appl. Entomol. 122:375-381.

51. Zhang, J., Miller, S., Hoy, C., Zhou, X., and Nault, L. 1998. A rapid method for detection and differentiation of aster-yellows phytoplasmainfected and inoculative leafhoppers. (Abstr.) Phytopathology 88(suppl.):S84. 